\title{
A Study on the Effects of Leadership Styles on Organizational Effectiveness \\ - Focusing on Small and Medium Enterprises -
}

$\mathrm{Ji}-$ chul Yoo $^{*} \cdot$ Young-wha Lee

*Dept. Of Industrial Management Engineering, Korea National University of Transportation

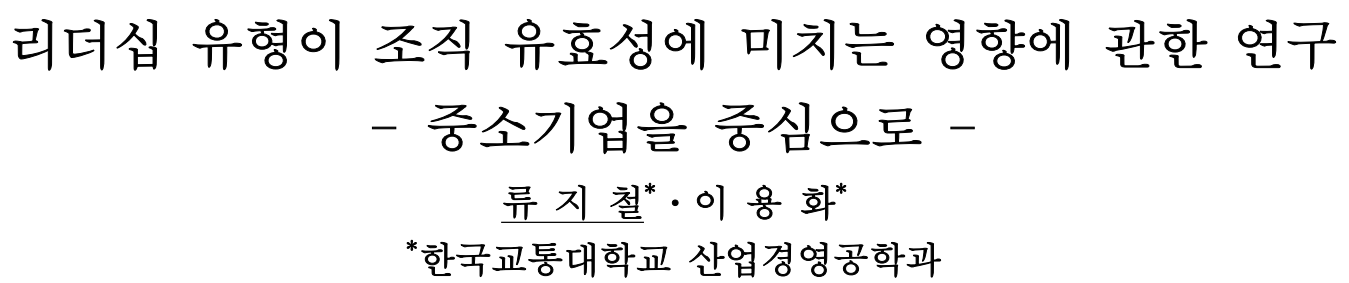

\begin{abstract}
조직에는 조직의 목적을 효율적으로 달성할 수 있도록 조직구성원들을 움직이게 하는 리더가 존재하게 된다. 조 직 내에 달성해야 할 비전과 목표가 있고 그것을 수행해야 할 과업에 있어서 가장 필요한 것은 구성원들의 비전과 목표를 달성하기 위한 리더십이 중요한 요인이다. 리더십은 비전과 목표달성을 위해 다른 사람들의 행동에 영향을 미치는 과정이기 때문이다. 따라서 모든 유형의 집단이나 조직, 그리고 지역사회나 국가에는 효과적인 리더십이 필 요하고 그 같은 효과적인 리더십을 발휘할 유능한 리더가 요구된다. 따라서 리더십은 모든 집단이나 조직의 중요한 자산이며 성공요인이 아닐 수 없다. 특히 중소기업의 경우 기업경영전반에 걸쳐 경영자의 기호나 의도에 따라 수시 로 변하는 경우가 많고, 최고 경영자의 개인적 속성이 조직구조나 전략에 적지 않은 영향을 미치기 때문에 최고경 영자의 리더십이 중소기업의 조직문화 형성에 대기업보다 훨씬 많은 영향을 미치고 있다. 변혁적 리더십은 사장이 카리스마, 지적자극, 개별적 배려 등을 통해 종업원들에게 기대를 능가하는 최고의 노력을 발휘하도록 동기부여 시 키는 것이다. 변혁적 리더십을 발휘하는 사장은 종업원들의 욕구수준을 높여 주고 자신감을 심어줌으로써 성공에 대한 확신을 높여준다면 종업원들로 하여금 조직에 대한 몰입을 이끌어 낼 수 있고, 보통이상의 추가노력과 낮은 이직의도를 거둘 수 있다는 것이다. 따라서 본 연구는 연구의 목적을 달성하기 위해 연구와 관련된 선행연구자들을 분석하고, 이를 토대로 연구모형을 설계하여 중소제조업체의 $\mathrm{CEO}$ 들에게 요구하는 리더십모형을 제시하였다. 중소 기업의 리더십 유형을 카리스마적, 전략적, 거래적, 변혁적 이론 등을 기본으로 하여 기업에 어떠한 영향을 주는지 를 이론을 통해 제시하였다. 이러한 리더십 유형들이 기업의 목표에 영향을 주는지를 분석한 후 여기에서 중소기업 의 $\mathrm{CEO}$ 에게 필요로 하는 리더십 유형을 제시하였다.
\end{abstract}

Keywords : 변혁적 - 거래적 리더십, 카리스마, 지적자극, 개별적 배려

1. Introduction

As business environment gets more complex than ever and companies pursue management innovation, their strategy of developing human resources become more complex and varied.

† 이 논문은 2012년도 한국교통대학교 교내학술연구비의 지원을 받아 수행한 연구임.

† 이용화, 충청북도 충주시 한국교통대학교 공과대학 산업경영공학과

M.P : 010-4174-1352,E-mail : yhlee@ut.ac.kr

2012년 7월 19일 접수; 2012년 9월 6일 수정본 접수; 2012년 9월 12일 게재확정 
Small and Medium enterprises struggle to survive the current age of keen competition through various management operations, but what is more important is that they should put in effort to improve the performance competence of members in their organizations and to solve the problems that follow. That is why the development of human resources is considered important.

Small and Medium enterprise is very important in the entire industry of Korea. Because, Small and Medium enterprise are the basis of industry.

The Small and Medium enterprise consist of 98.5\% of all enterprises, and the employees consist of $86.5 \%$ of all workers in 2009. In spite of great important in industry of korea. It is absolutely and relatively poor. Especially, the $\mathrm{CEO}$ of small and medium enterprise (SMEs) has influences on the all parts of the enterprise such as leadership, However, most of all previous studies have focused on the large company. Therefore, this study addresses on the effect of the leadership of CEO in the SMEs on the organization immersion of SMEs.

The purpose of this study is to affect transformational leadership and transactional leadership on organizational effectiveness and to investigate the relationship between organizational effectiveness. Also we have to investigate the relationship between organizational effectiveness and transactional relationship and transactional leadership of medium and small enterprises.

\section{The power, trait and behavior of leaders}

\subsection{Leaders gain and use the power}

Another essential ingredient of effective leadership is the power-the ability to get others to do what you want them to do. Effective managerial leaders use the power wisely, and they maintain bases of the power derived from several sources. The power may be gained through the manager's formal position in the organization and or through personal sources. Position power is based on rewards, coerction, and legitimacy. Personal power is based on expertise and reference. Very importantly, effective leaders empower others that is, they help and allow others to take action and make decisions on their own on matters relevant to their job performance. Today's organizations depend on empowerment to create "lateral" and "bottom-up" leadership to supplement the more traditional "top-down" leadership of the past.

\subsection{The important leadership traits and behaviors}

Early leadership research emphasized the study of personal traits and sought to isolate a profile of traits that differentiated successful and unsuccessful leaders. Current thinking recognized traits mainly as possible foundations for building appropriate lead-ership skills. Important traits in this regard include drive, integrity, and self confidence, among others. Another leadership approach focuses the study of leader behaviors. Here, a special interest rests with how followers respond to task-oriented and people-oriented behaviors by leaders. A popular "managerial grid" identifies the leader who is high in concerns for both task and people as a most effective one. Developments in contingency leadership thinking, how-ever, try to identify when different leader behaviors would best meet the needs of different types of leadership situations.

\section{Transformation Leadership}

It is "inspirational" leadership that influences the beliefs, values, and expectations of followers, and gets them to do things different from what they originally anticipated being willing or able to do. Vision, charisma, symbolism, empowerment, intellectual stimulation, and integrity are all things that transformational leaders contribute to work situations. Additional developments in leadership thinking now emphasize the importance of transformational leaders to all organizations. In many ways, this is leadership that adds "personality" to the work place and creates high levels of commitment and effort due to the contagious enthusiasm it generates.

Vision : Having ideas and a clear sense of 
direction, being able to communicate visions to others, and developing in them a sense of great excitement about working hard to accomplish shared "dreams."

Charisma : Arousing others' enthusiasm, faith, loyalty, pride, and trust in them-selves through the power of personal reference and appeals to emotion.

Symbolism : Identifying "heroes," offering special rewards, and holding spontaneous and planned ceremonies to celebrate excellence and high achievement.

Empowerment : Maintaining a developmental orientation toward others, re-moving performance obstacles, sharing responsibilities, and delegating truly challenging work.

Intellectual stimulation : Enhancing the mental involvement of others by creating awareness of problems and stirring their imagination to create high quality solutions.

Integrity : Being honest and credible, acting consistently out of a sense of personal conviction, and above all meeting commitments by following through doing what you said you would.

\section{Study Model}

This study is about understanding the effectiveness of the type of leadership through the analysis in $\mathrm{CEO}^{\prime} \mathrm{s}$ transformational leadership and transactional leadership on organizational effectiveness.

\subsection{Study Hypothesis}

1) Relationship between Transforming Leadership and Organizational Effectiveness

Hypothesis 1-1. Charisma factor in transforming leadership will have a positive relationship with organizational effectiveness.

Hypothesis 1-2. Individualized consideration in transforming leadership will have a positive relationship with organizational effectiveness.

Hypothesis 1-3. Intellectual stimulation in transforming leadership will have a positive relationship with organizational effectiveness.

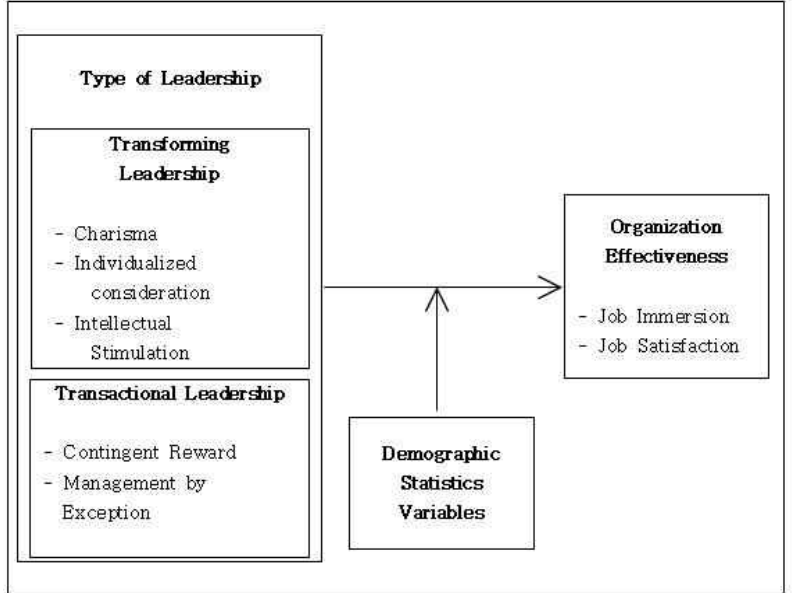

$<$ Figure 1 $>$ Study Model

2) Relationship between Transactional Leadership and Organizational Effectiveness

Hypothesis 2-1. Contingent reward factor in transactional leadership will have a positive relationship with organizational effectiveness.

Hypothesis 2-2. Management by exception factor in transactional leadership will have a positive relationship with organizational effectiveness.

3) Regulation Relationship Of Demographic Statistics Variables (Position, Duration of years)

Hypothesis 3-1. Position will be in the role in the regulation between charisma factor and organizational effectiveness.

Hypothesis 3-2. Duration of years will be in the role in the regulation between charisma factor and organizational effectiveness.

Hypothesis 3-3. Position will be in the role in the regulation between individualized consideration and organizational effectiveness.

Hypothesis 3-4. Duration of years will be in the role in the regulation between individualized consideration and organizational effectiveness.

Hypothesis 3-5. Position will be in the role in the regulation between intellectual stimulation and organizational effectiveness.

Hypothesis 3-6. Duration of years will be in the role in the regulation between intellectual stimulation and organizational effectiveness.

Hypothesis 3-7. Position will be in the role in the regulation between contingent reward and organizational effectiveness. 
Hypothesis 3-8. Duration of years will be in the role in the regulation between contingent reward and organizational effectiveness.

Hypothesis 3-9. Position will be in the role in the regulation between management by exception and organizational effectiveness.

Hypothesis 3-10. Duration of years will be in the role in the regulation between management by exception and organizational effectiveness.

\subsection{Analysis Conclusion}

\section{1) Collection of data}

The subjects for questionnaires of this study were incumbents in enterprise. Each item of the questionnaires was evaluated by 5 point scales. The test of the research hypotheses was performed through frequency analysis, factorial analysis, reliability analysis of variance, using SPSS 18.0 and for hypothesis testing the regression analysis was conducted.

The survey was conducted during 40 days in $2012(2 / 10 \sim 3 / 20)$ and 300 copy was distributed. Excluding insincerity ones among them, total 250 copy was used in final analysis.

$<$ Table 1> Demographic Characteristics

\begin{tabular}{|c|c|c|c|}
\hline \multicolumn{2}{|c|}{ Classify } & Frequency & Percentage (\%) \\
\hline \multirow{2}{*}{ Sex } & male & 185 & 74.0 \\
\hline & female & 65 & 26.0 \\
\hline \multirow{4}{*}{ Age } & $\begin{array}{c}\text { between } \\
20-30\end{array}$ & 102 & 40.8 \\
\hline & $\begin{array}{c}\text { between } \\
30-40\end{array}$ & 70 & 28.0 \\
\hline & $\begin{array}{c}\text { between } \\
40-50\end{array}$ & 58 & 23.2 \\
\hline & $\begin{array}{c}\text { between } \\
50-60\end{array}$ & 20 & 8.0 \\
\hline \multirow{3}{*}{ Position } & worker & 116 & 46.4 \\
\hline & chief & 63 & 25.2 \\
\hline & $\begin{array}{l}\text { head of } \\
\text { section }\end{array}$ & 71 & 28.4 \\
\hline \multirow{4}{*}{$\begin{array}{c}\text { Duration of } \\
\text { years }\end{array}$} & under 2 years & 38 & 15.2 \\
\hline & $\begin{array}{l}\text { between } 3-5 \\
\text { years }\end{array}$ & 79 & 31.6 \\
\hline & $\begin{array}{c}\text { between 5-7 } \\
\text { years }\end{array}$ & 64 & 25.6 \\
\hline & above 7 years & 69 & 27.6 \\
\hline \multicolumn{2}{|c|}{ Total } & 250 & 100 \\
\hline
\end{tabular}

\subsection{Evaluation of Measurement Items}

\section{1) Factor Analysis}

In this study to test the validity of questionnaires and to find a common factor to apply as an variables, factor analysis were used. Factor Analysis is used to secure the factors that were not directly measured based on measured variables. Simplifying the result by making variables into few numbers of factors are primary goal (main purpose). Principle Components were used in this study and only factors that are above designated eigenvalue were extracted. Verimax rotation was used in factor rotation. Factor Loading shows correlation between each factor of variables. In general, over \pm 0.4 are significant and in this study this was selected to be a standard. Eigenvalue shows how each factor can be explained about entire dispersion and over 1 was selected to be a standard.

\section{2) Reliability Analysis}

Reliability indicates accuracy or precision of measurement tools and it has a same meaning as dependability, stability, consistency, predictability, and accuracy. Reliability analysis has a premise that the result of the data should be similar if the similar concept was measured in dependent measurement method.

Reliability is a concept that does not contain the degree of error in measurements result. In other words, it is a degree of amount that reflects systematic information about dispersion. That is, the little the amount of degree that is included in grade of measurement, the more the measurement will be reliable.

Reliability measurement such as Cronbach's alpha is normally used in reliability analysis and alpha is focused on internal consistency of the test which is to know whether test items are consisted in homogeneous factor.

Therefore, in this study, to test the reliability of measurement question Cronbach's alpha is used to evaluate the reliability of individual item and entire item

In general, value of Cronbach's alpha which is standards of reliability is over .60, it is judged reliable. 
$<$ Table 2> Result of Factor Analysis

\begin{tabular}{|c|c|c|c|c|c|}
\hline & & & $\begin{array}{l}\text { loads } \\
\text { factor }\end{array}$ & eigenvalue & $\begin{array}{c}\text { accumulate } \\
\text { variance }\end{array}$ \\
\hline \multirow{9}{*}{$\begin{array}{l}\text { Transformin } \\
\text { g Leadership }\end{array}$} & \multirow{3}{*}{ charisma } & Inject them to have a pride on themselves & .886 & \multirow{3}{*}{2.593} & \multirow{3}{*}{14.090} \\
\hline & & $\begin{array}{c}\text { Transcend CEO's own profit for the group } \\
\text { profit }\end{array}$ & .879 & & \\
\hline & & Act as to make subordinate to respect you & .853 & & \\
\hline & \multirow{3}{*}{$\begin{array}{l}\text { individualized } \\
\text { consideration }\end{array}$} & $\begin{array}{l}\text { Spend time to teach and instruct the } \\
\text { subordinate }\end{array}$ & .828 & \multirow{3}{*}{1.994} & \multirow{3}{*}{16.114} \\
\hline & & Treat subordinate as human being & .780 & & \\
\hline & & Help subordinate to develop their ability & .704 & & \\
\hline & \multirow{3}{*}{$\begin{array}{l}\text { intellectual } \\
\text { stimulation }\end{array}$} & $\begin{array}{l}\text { Check subordinate whether they are doing } \\
\text { their duty properly }\end{array}$ & .865 & \multirow{3}{*}{3.721} & \multirow{3}{*}{24.806} \\
\hline & & $\begin{array}{l}\text { Instruct to make them have a different } \\
\text { perspectives of the problem }\end{array}$ & .850 & & \\
\hline & & Propose a new method for job completion & .834 & & \\
\hline \multirow{6}{*}{$\begin{array}{l}\text { Transactional } \\
\text { Leadership }\end{array}$} & \multirow{3}{*}{$\begin{array}{l}\text { contingent } \\
\text { reward }\end{array}$} & Help them as a reward of job effort & .811 & \multirow{3}{*}{2.103} & \multirow{3}{*}{10.513} \\
\hline & & $\begin{array}{l}\text { Clearly propose the reward when the goal is } \\
\text { achieved }\end{array}$ & .739 & & \\
\hline & & $\begin{array}{l}\text { Show satisfaction when one's expectations } \\
\text { comes out }\end{array}$ & .829 & & \\
\hline & \multirow{3}{*}{$\begin{array}{l}\text { management } \\
\text { by exception }\end{array}$} & Don't interfere until the problems get serious & .825 & \multirow{3}{*}{2.510} & \multirow{3}{*}{58.822} \\
\hline & & $\begin{array}{l}\text { Attention of whether subordinate makes a } \\
\text { mistake }\end{array}$ & .713 & & \\
\hline & & $\begin{array}{l}\text { Dislike to be participated when significant } \\
\text { problem occurred }\end{array}$ & .604 & & \\
\hline \multirow{6}{*}{$\begin{array}{l}\text { Organization } \\
\quad \text { al } \\
\text { Effectiveness }\end{array}$} & \multirow{3}{*}{$\begin{array}{c}\text { job } \\
\text { immersion }\end{array}$} & True interest on the company & .819 & \multirow{3}{*}{2.170} & \multirow{3}{*}{24.107} \\
\hline & & Make an effort for the company's success & .762 & & \\
\hline & & Pride of being a member of the company & .703 & & \\
\hline & \multirow{3}{*}{$\begin{array}{c}\text { job } \\
\text { satisfaction }\end{array}$} & Satisfaction on one's work & .761 & \multirow{3}{*}{1.909} & \multirow{3}{*}{21.212} \\
\hline & & $\begin{array}{l}\text { Satisfaction on opportunity to develop oneself } \\
\text { by work }\end{array}$ & .756 & & \\
\hline & & Satisfaction on overall company & .684 & & \\
\hline
\end{tabular}

$<$ Table 3> Result of Analysis

\begin{tabular}{|c|c|c|c|}
\hline \multicolumn{2}{|c|}{ Variable } & 항목수 & $\begin{array}{c}\text { Reliability Coefficient } \\
\text { (Cronbach's alpha) }\end{array}$ \\
\hline \multirow{2}{*}{$\begin{array}{c}\text { Transforming } \\
\text { Leadership }\end{array}$} & Charisma & 3 & .878 \\
\cline { 2 - 4 } & Individualized consideration & 3 & .832 \\
\cline { 2 - 4 } & Intellectual stimulation & 3 & .783 \\
\hline Transactional & Contingent reward & 3 & .883 \\
\cline { 2 - 4 } Leadership & Management by exception & 3 & .819 \\
\hline Organizational & Job immersion & 3 & .801 \\
\cline { 2 - 4 } Effectiveness & Job satisfaction & 3 & .774 \\
\hline
\end{tabular}




\section{Result of Methodology}

\subsection{Relationship between Transforming}

Leadership and Organizational Effectiveness

Among types of CEO's leadership, consequence of multiple regression analysis between transforming leadership and organizational effectiveness is shown as followed.

$<$ Table 4> Result of multiple regression analysis between transforming leadership and organizational effectiveness

\begin{tabular}{|c|c|c|c|c|c|}
\hline \multirow[b]{2}{*}{ Model } & \multicolumn{2}{|c|}{$\begin{array}{c}\text { non standard } \\
\text { index }\end{array}$} & \multirow{2}{*}{$\begin{array}{c}\begin{array}{c}\text { standard } \\
\text { index }\end{array} \\
\text { Beta }\end{array}$} & \multirow{2}{*}{$\begin{array}{c}\mathrm{t} \\
\text { valu } \\
\mathrm{e}\end{array}$} & \multirow{2}{*}{$\begin{array}{c}\text { significa } \\
\text { nce } \\
\text { probabilit } \\
y\end{array}$} \\
\hline & B & $\begin{array}{l}\text { stand } \\
\text { ard } \\
\text { error }\end{array}$ & & & \\
\hline (Invariable) & 2.100 & .289 & & & 7.266 \\
\hline Charisma & .189 & .069 & .215 & $\begin{array}{c}2.72 \\
6\end{array}$ & .007 \\
\hline $\begin{array}{l}\text { Individualized } \\
\text { consideration }\end{array}$ & .157 & .058 & .217 & $\begin{array}{c}2.71 \\
3\end{array}$ & .007 \\
\hline $\begin{array}{l}\text { Intellectual } \\
\text { stimulation }\end{array}$ & .155 & .065 & .201 & $\begin{array}{c}2.39 \\
1 \\
\end{array}$ & .018 \\
\hline adj R2:.182 & & $\begin{array}{r}: 10.0 \\
.00\end{array}$ & signi & $\mathrm{e}$ & bability : \\
\hline
\end{tabular}

\subsection{Relationship between Transactional}

\section{Leadership and Organizational Effectiveness}

Among types of CEO's leadership, consequence of multiple regression analysis between transactional leadership and organizational effectiveness is shown as followed.
$<$ Table 5> Result of multiple regression analysis between transactional leadership and organizational effectiveness

\begin{tabular}{|c|c|c|c|c|c|}
\hline \multirow[b]{2}{*}{ Model } & \multicolumn{2}{|c|}{$\begin{array}{c}\text { non standard } \\
\text { index }\end{array}$} & \multirow{2}{*}{$\begin{array}{c}\text { standard } \\
\text { index } \\
\text { Beta }\end{array}$} & \multirow{2}{*}{$\begin{array}{c}\mathrm{t} \\
\text { valu } \\
\mathrm{e}\end{array}$} & \multirow{2}{*}{$\begin{array}{c}\text { signific } \\
\text { ance } \\
\text { probabi } \\
\text { lity }\end{array}$} \\
\hline & B & $\begin{array}{l}\text { stand } \\
\text { ard } \\
\text { error }\end{array}$ & & & \\
\hline (Invariable) & 2.820 & .291 & & $\begin{array}{c}9.70 \\
6\end{array}$ & .000 \\
\hline $\begin{array}{c}\text { Contingent } \\
\text { reward }\end{array}$ & .177 & .070 & .214 & $\begin{array}{c}2.53 \\
3\end{array}$ & .001 \\
\hline $\begin{array}{l}\text { Management } \\
\text { by exception }\end{array}$ & .059 & .058 & .087 & $\begin{array}{c}1.01 \\
5\end{array}$ & .034 \\
\hline adj R2 : .166 & & $\begin{array}{r}3.867 \\
.004\end{array}$ & significar & proba & bility : \\
\hline
\end{tabular}

\subsection{Regulation Relationship Of Demo graphic Statistics Variables (Position, Duration of years)}

To verify the hypothesis about whether demographic statistics variables(position, duration of years) shows the regulation effectiveness in effective relationship between transforming leadership and organizational effectiveness, the study was verified by using control regression analysis. To achieve this, dependent variable was put to be organizational effectiveness, and independent variable in step one was just put in to component of transforming leadership and regression analysis was conducted.

$<$ Table 6> Result of test about Adjusted Effectiveness of position between transforming leadership and organizational effectiveness

\begin{tabular}{|c|c|c|c|c|c|c|c|c|c|c|}
\hline \multirow{2}{*}{\multicolumn{2}{|c|}{ Model }} & \multirow[b]{2}{*}{$\mathrm{R}$} & \multirow[b]{2}{*}{$\mathrm{R} 2$} & \multirow{2}{*}{$\begin{array}{l}\text { modified } \\
\mathrm{R}-\text { square }\end{array}$} & \multirow{2}{*}{$\begin{array}{c}\text { estimation of } \\
\text { standard } \\
\text { error }\end{array}$} & \multicolumn{5}{|c|}{ statistics variance } \\
\hline & & & & & & $\begin{array}{l}\text { variance of } \\
\mathrm{R} \text {-square }\end{array}$ & $\begin{array}{c}\text { variance } \\
\text { of } \mathrm{F}\end{array}$ & $\begin{array}{l}\text { degree of } \\
\text { freedom }\end{array}$ & $\begin{array}{l}\text { degree of } \\
\text { freedom }\end{array}$ & $\begin{array}{c}\text { variance of } \\
\text { significance } \mathrm{F}\end{array}$ \\
\hline \multirow{3}{*}{ Charisma } & 1 & $.710(\mathrm{a})$ & .504 & .503 & .496571 & .504 & 969.258 & 1 & 954 & .000 \\
\hline & 2 & $.752(\mathrm{~b})$ & .566 & .565 & .46462 & .062 & 136.458 & 1 & 953 & .000 \\
\hline & 3 & $.653(\mathrm{c})$ & .521 & .526 & .46419 & .001 & 2.785 & 1 & 952 & .005 \\
\hline \multirow{3}{*}{$\begin{array}{l}\text { Individual } \\
\text { ized } \\
\text { considerat } \\
\text { ion }\end{array}$} & 1 & $.674(\mathrm{a})$ & .454 & .454 & .52068 & .454 & 794.852 & 1 & 954 & .000 \\
\hline & 2 & $.716(\mathrm{~b})$ & .513 & .512 & .49210 & .059 & 115.043 & 1 & 953 & .000 \\
\hline & 3 & $.717(\mathrm{c})$ & .514 & .512 & .49222 & .000 & .534 & 1 & 952 & .465 \\
\hline \multirow{3}{*}{$\begin{array}{c}\text { Intellectu } \\
\text { al } \\
\text { stimulatio } \\
\mathrm{n}\end{array}$} & 1 & $.660(\mathrm{a})$ & .436 & .435 & .52942 & .436 & 797.588 & 1 & 954 & .000 \\
\hline & 2 & $.705(\mathrm{~b})$ & .498 & .496 & .49999 & .061 & 116.631 & 1 & 953 & .000 \\
\hline & 3 & $.701(\mathrm{c})$ & .496 & .494 & .49992 & .001 & 1.271 & 1 & 952 & .260 \\
\hline
\end{tabular}


Step 1 : Regression analysis between independent variable and dependent variable

Step 2 : Regression analysis between independent variable, regulate variable and dependent variable

Step 3 : Regression analysis between independent variable, regulate variable, interaction term (independent variable*regulate variable) and dependent variable

To verify the hypothesis about whether demographic statistics variables(position, duration of years) shows the regulation effectiveness in effective relationship between transactional leadership and organizational effectiveness, the study was verified by using control regression analysis. To achieve this, dependent variable was put to be organizational effectiveness, and independent variable in step one was just put in to component of transactional leadership and regression analysis was conducted.

Step 1 : Regression analysis between independent variable and dependent variable

Step 2 : Regression analysis between independent variable, regulate variable and dependent variable Step 3 : Regression analysis between independent variable, regulate variable, interaction term (independent variable*regulate variable) and dependent variable

$<$ Table $7>$ Result of test about adjusted effectiveness of duration of years between transforming leadership and organizational effectiveness

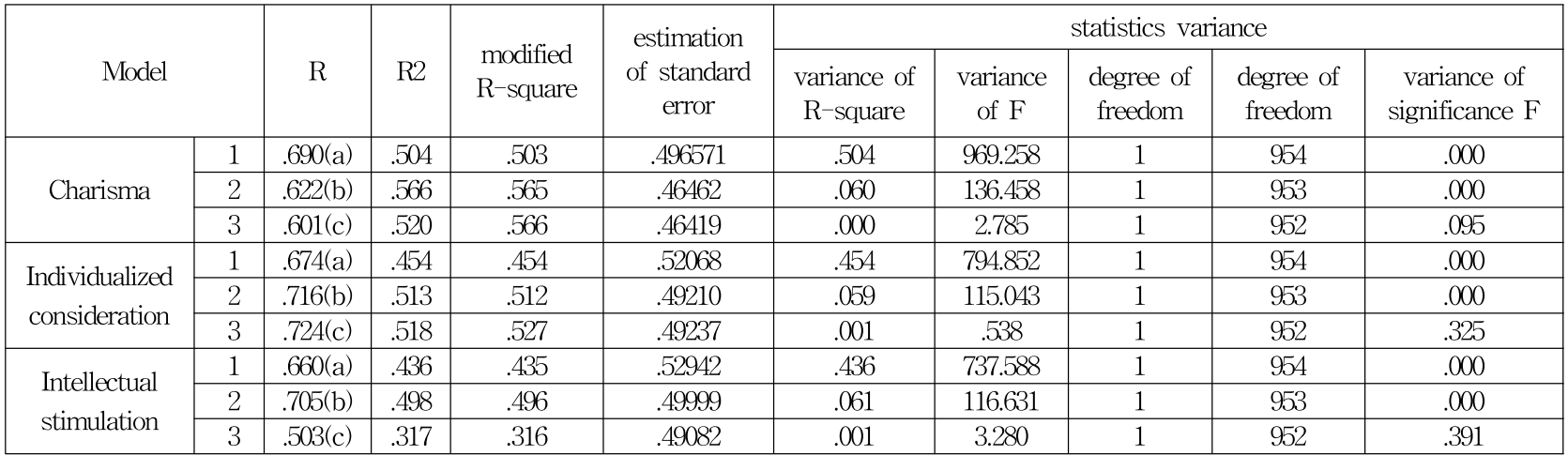

$<$ Table 8> Result of test about adjusted effectiveness of position between transactional leadership and organizational effectiveness

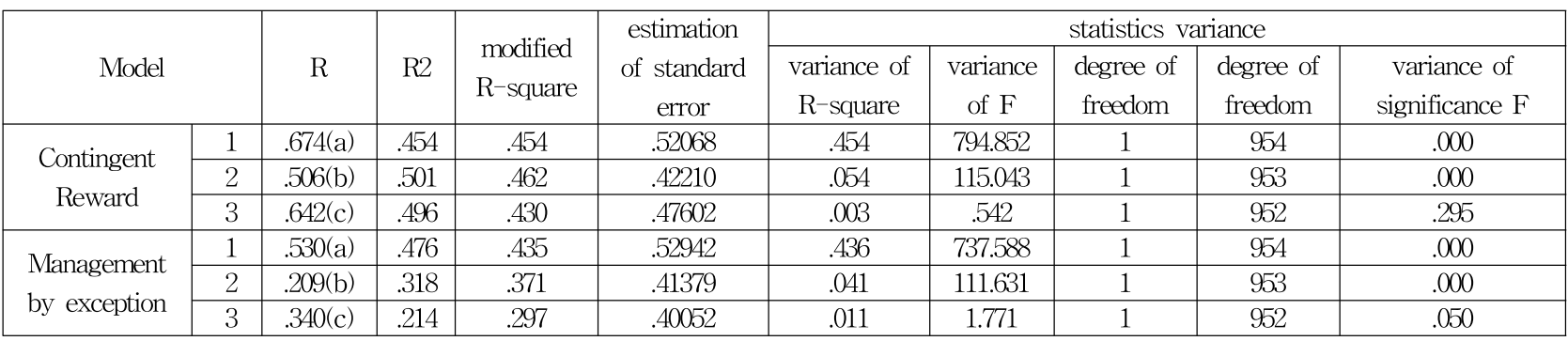

$<$ Table 9> Result of test about adjusted effectiveness of duration of years between transactional leadership and organizational effectiveness

\begin{tabular}{|c|c|c|c|c|c|c|c|c|c|c|}
\hline \multirow{2}{*}{\multicolumn{2}{|c|}{ Model }} & \multirow[b]{2}{*}{$\mathrm{R}$} & \multirow[b]{2}{*}{$\mathrm{R} 2$} & \multirow[b]{2}{*}{$\begin{array}{l}\text { modified } \\
\mathrm{R}-\text { square }\end{array}$} & \multirow{2}{*}{$\begin{array}{c}\text { estimation } \\
\text { of standard } \\
\text { error }\end{array}$} & \multicolumn{5}{|c|}{ statistics variance } \\
\hline & & & & & & $\begin{array}{c}\text { variance of } \\
R \text {-square }\end{array}$ & $\begin{array}{l}\text { variance } \\
\text { of } \mathrm{F}\end{array}$ & $\begin{array}{l}\text { degree of } \\
\text { freedom }\end{array}$ & $\begin{array}{l}\text { degree of } \\
\text { freedom }\end{array}$ & $\begin{array}{c}\text { variance of } \\
\text { significance } F\end{array}$ \\
\hline \multirow{3}{*}{$\begin{array}{c}\text { Contingent } \\
\text { Reward }\end{array}$} & 1 & $.674(\mathrm{a})$ & .454 & .454 & .53178 & .454 & 727.852 & 1 & 954 & .000 \\
\hline & 2 & $.716(\mathrm{~b})$ & .513 & .512 & .49210 & .059 & 106.043 & 1 & 953 & .000 \\
\hline & 3 & $.816(\mathrm{c})$ & .514 & .512 & .49222 & .000 & .534 & 1 & 952 & .279 \\
\hline \multirow{3}{*}{$\begin{array}{l}\text { Management } \\
\text { by exception }\end{array}$} & 1 & $.660(a)$ & .436 & .435 & .52139 & .436 & 729.537 & 1 & 954 & .000 \\
\hline & 2 & .716 (b) & .498 & .496 & .40999 & .061 & 116.631 & 1 & 953 & .000 \\
\hline & 3 & $.794(\mathrm{c})$ & .498 & .497 & .49992 & .001 & 11.271 & 1 & 952 & .180 \\
\hline
\end{tabular}


$<$ Table 10> Conclusion of the Hypothesis

\begin{tabular}{|c|c|}
\hline Hypothesis & Results \\
\hline $\begin{array}{l}\text { Hypothesis } 1-1 . \\
\text { Charisma factor in transforming leadership will have a positive relationship with } \\
\text { organizational effectiveness. }\end{array}$ & O \\
\hline $\begin{array}{l}\text { Hypothesis } 1-2 . \\
\text { Individualized consideration in transforming leadership will have a positive } \\
\text { relationship with organizational effectiveness. }\end{array}$ & O \\
\hline $\begin{array}{l}\text { Hypothesis } 1-3 . \\
\text { Intellectual stimulation in transforming leadership will have a positive relationship } \\
\text { with organizational effectiveness. }\end{array}$ & O \\
\hline $\begin{array}{l}\text { Hypothesis } 2-1 . \\
\text { Contingent reward factor in transactional leadership will have a positive } \\
\text { relationship with organizational effectiveness. }\end{array}$ & O \\
\hline $\begin{array}{l}\text { Hypothesis } 2-2 \text {. } \\
\text { Management by exception factor in transactional leadership will have a positive } \\
\text { relationship with organizational effectiveness. }\end{array}$ & $x$ \\
\hline $\begin{array}{l}\text { Hypothesis } 3-1 . \\
\text { Position will be in the role in the regulation between charisma factor and } \\
\text { organizational effectiveness. }\end{array}$ & $\times$ \\
\hline $\begin{array}{l}\text { Hypothesis } 3-2 . \\
\text { Duration of years will be in the role in the regulation between charisma factor } \\
\text { and organizational effectiveness. }\end{array}$ & $\times$ \\
\hline $\begin{array}{l}\text { Hypothesis } 3-3 \text {. } \\
\text { Position will be in the role in the regulation between individualized consideration } \\
\text { and organizational effectiveness. }\end{array}$ & O \\
\hline $\begin{array}{l}\text { Hypothesis } 3-4 \text {. } \\
\text { Duration of years will be in the role in the regulation between individualized } \\
\text { consideration and organizational effectiveness. }\end{array}$ & O \\
\hline $\begin{array}{l}\text { Hypothesis } 3-5 \text {. } \\
\text { Position will be in the role in the regulation between Intellectual stimulation and } \\
\text { organizational effectiveness. }\end{array}$ & $\times$ \\
\hline $\begin{array}{l}\text { Hypothesis } 3-6 . \\
\text { Duration of years will be in the role in the regulation between Intellectual } \\
\text { stimulation and organizational effectiveness. }\end{array}$ & $\times$ \\
\hline $\begin{array}{l}\text { Hypothesis } 3-7 . \\
\text { Position will be in the role in the regulation between contingent reward and } \\
\text { organizational effectiveness. }\end{array}$ & $\times$ \\
\hline $\begin{array}{l}\text { Hypothesis } 3-8 . \\
\text { Duration of years will be in the role in the regulation between contingent reward } \\
\text { and organizational effectiveness. }\end{array}$ & 0 \\
\hline $\begin{array}{l}\text { Hypothesis } 3-9 . \\
\text { Position will be in the role in the regulation between management by exception } \\
\text { and organizational effectiveness. }\end{array}$ & $x$ \\
\hline $\begin{array}{l}\text { Hypothesis } 3-10 . \\
\text { Duration of years will be in the role in the regulation between management by } \\
\text { exception and organizational effectiveness. }\end{array}$ & O \\
\hline
\end{tabular}




\section{Conclusion}

Results in this paper, as shown in <Table 10>, Charisma, individualized consideration and intellectual stimulation in Transforming Leadership have positive relationship with organizational effectiveness. On the contrary, In was shown that position and duration of years individually controls between consideration factor and organizational effectiveness.

However, position and duration of years have a small influence in controlling between intellectual stimulation and organizational effectiveness. Also position has a small influence on controlling between contingent reward and organizational effectiveness. The study was shown that duration of years has an influence as controlling factor between contingent reward and management by exception whereas position has a slight influence as controlling factor between management by exception factor and organizational effectiveness. Transforming leadership is an motivation that makes the employees to show their best effort that surpass the expectation though CEO's charisma, intellectual stimulation, individualized consideration and so on

If $\mathrm{CEO}$ who shows transforming leadership boosts the assurance of their success by increasing desire level of the employee and giving them self-confidence, it will lead the employee to engage more to the organization and also above normal level of extra effort and low turnover intention will be achieved.

It was noted that for transforming leadership, charisma, individualized consideration factor and intellectual stimulation factor have an significant in organizational effectiveness. It was also shown that duration of years has a big impact. Therefore as to transforming leadership and transactional leadership, CEOs in the small and medium-sized enterprise can increase the organizational effectiveness by selecting and managing the significant of factor.

Transforming leadership is to heighten the leadership reliable level of subordinates, serving as a good model that CEO can satisfy himself for the organization. On the other hand, transactional leadership is to lead the subordinates through the promotion, recognition or rewards. There is not a desirable model of leadership for all situations and the definition of leadership is also changing by various reasons. Thus the research on the leadership in the future should draw diverse conclusions by changing relevant variables.

Because of the limited area of survey object in this study, it is estimated that the samples are insufficient to represent the Population. Also, because of the lack of diversity in survey method that was used in hypothesis testing, interpretation of the survey could have been different caused by the limited area of the respondent. For the future study, this limitation will be supplemented and should be studied variously.

\section{References}

[1] 고성돈, 송병식, “변혁적 리더십이 구성원의 임파워 먼트와 조직유효성에 미치는 영향에 관한 실증적 연구," 대한경영학회, 대한경영학회지, 23호, 2000.

[2] 김경수, 김정남, " 변혁적 리더십이 조직성과와 직 무만족에 미치는 영향," 산업경제연구, 제 20집, 전 남대학교기업경영연구소, 1996.

[3] 김상도(1999), “리더십 유형이 조직성과에 미치는 영향에 관한 실증적 연구” , 연세대학교 경영대학 원, 석사학위논문.

[4] 배종갑(2003), "중소기업 $\mathrm{CEO}$ 의 리더십 유형과 조 직성과에 관한 연구” , 국립창원대학교 경영대학원, 석사학위 논문

[5] 양덕근(2003), "리더의 리더십 유형이 조직문화에 미치는 영향에 관한 연구” , 중앙대학교 대학원, 석 사학위 논문

[6] 이기화(2004), "중소기업 경영자의 리더십이 유형이 기술개발에 미치는 영향에 관한 연구” , 동의대학 교 경영대학원 석사학위 논문

[7] 정완영(2005), "중소기업 $\mathrm{CEO}$ 의 리더십 유형에 따 른 직무만족과 직무성과간의 관계 대한 연구” , 가 톨릭대학교 경영대학원 석사학위 논문

[8] Bass B. M "From Transactional to Transformational Leadership," Organizational Dynamics, 1998, 307-330

[9] Bass B. M. and yokochi N. , "Charisma among Senior Executives and the Special Case of Japanese CEO‘S Consulting," Psychology Bulletin. Winter/Spring 1991, 231-272 


\section{저 자 소 개}

류 지 철

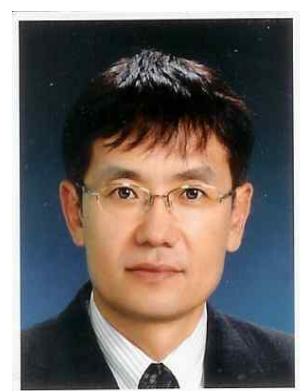

동국대학교 산업공학과 및 동 대 학원을 졸업하고 Adamson University에서 박사를 수료한 후, University of Windsor에서 1 년 6 개월 간 연구원으로 재직. 한국산업개발연구원에서 연구원 을 거친 후 현재 충주대학교 산 업경영공학과에 교수로 재직중. 관심분야는 Ergonomics와 기업에서의 인적자원에 관한 분야이다. 현재 사단법인 경영기술연구원 이사, (주)입 소 경영자문위원, 한국산업인력공단 $\mathrm{HRD}$ 전문위원, 노 동부 충북고용포럼위원장, 국가품질상 심사위원(지경부) 주소: 충청북도 충주시 한국교통대학교 공과대학 산업 경영공학과
이 용 화

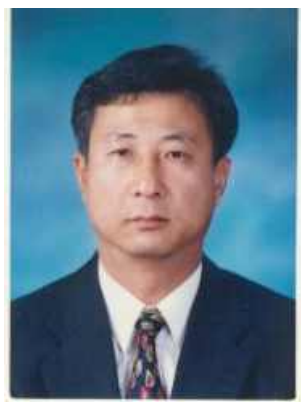

동국대학교를 졸업하고 청주대학 교 대학원에서 경영학박사를 취 득. 현재 한국교통대학교 산업경 영공학과에 재직중

관심분야는 산업현장의 안전관리 분야와 경영정보분야임.

주소: 충청북도 충주시 한국교통대학교 공과대학 산업 경영공학과 